\title{
Survival of Laryngeal Cancer Patients Depending on Zinc Serum Level and Oxidative Stress Genotypes
}

\author{
Jakub Lubiński ${ }^{1, *}$, Ewa Jaworowska ${ }^{1}$, Róża Derkacz ${ }^{2}$, Wojciech Marciniak ${ }^{2}$, Katarzyna Białkowska ${ }^{3}$, \\ Piotr Baszuk $^{3}$ (D), Rodney J. Scott ${ }^{4,5}$ and Jan A. Lubiński ${ }^{2,3}$ (D) \\ 1 Clinic of Otolaryngology, Pomeranian Medical University, Unii Lubelskiej 1, 71-252 Szczecin, Poland; \\ jaworowska@tlen.pl \\ 2 ReadGene, Alabastrowa 8, 72-003 Grzepnica, Poland; roza.derkacz@gmail.com (R.D.); \\ wojciech.marciniak90@gmail.com (W.M.); lubinski@pum.edu.pl (J.A.L.) \\ 3 Department of Genetics and Pathology, International Hereditary Cancer Centre, Pomeranian Medical \\ University, Unii Lubelskiej 1, 71-252 Szczecin, Poland; katarzyna.bialkowska@pum.edu.pl (K.B.); \\ baszukpiotr@gmail.com (P.B.) \\ 4 Discipline of Medical Genetics, Faculty of Health, School of Biomedical Sciences, University of Newcastle, \\ Callaghan, NSW 2308, Australia; rodney.scott@newcastle.edu.au \\ 5 The Hunter Medical Research Institute, Kookaburra Cct, New Lambton Heights, NSW 2305, Australia \\ * Correspondence: lubinski.kuba@gmail.com
}

check for

updates

Citation: Lubiński, J.; Jaworowska, E.; Derkacz, R.; Marciniak, W.;

Białkowska, K.; Baszuk, P.; Scott, R.J.; Lubiński, J.A. Survival of Laryngeal Cancer Patients Depending on Zinc Serum Level and Oxidative Stress Genotypes. Biomolecules 2021, 11, 865. https://doi.org/10.3390/

biom 11060865

Academic Editor: Krzysztof Szyfter

Received: 11 May 2021

Accepted: 7 June 2021

Published: 10 June 2021

Publisher's Note: MDPI stays neutral with regard to jurisdictional claims in published maps and institutional affiliations.

Copyright: (c) 2021 by the authors. Licensee MDPI, Basel, Switzerland. This article is an open access article distributed under the terms and conditions of the Creative Commons Attribution (CC BY) license (https:// creativecommons.org/licenses/by/ $4.0 /)$.

\begin{abstract}
Stress contributes to various aspects of malignancy and could influence survival in laryngeal cancer patients. Among antioxidant mechanisms, zinc and the antioxidant enzymes superoxide dismutase 2 , catalase and glutathione peroxidase 1 play a major role. The aim of this study was a prospective evaluation of the survival of patients with laryngeal cancer in relation to serum levels of zinc in combination with functional genotype differences of three key antioxidant enzymes. The study group consisted of 300 patients treated surgically for laryngeal cancer. Serum zinc levels and common polymorphisms in SOD2, CAT and GPX1 were analyzed. The risk of death in patients with the lowest zinc levels was increased in comparison with patients with the highest levels. Polymorphisms of antioxidant genes by themselves were not correlated with survival, however, serum zinc level impact on survival was stronger for SOD2 TC/TT and CAT CC variants. GPX1 polymorphisms did not correlate with zinc levels regarding survival. In conclusion, serum zinc concentration appears to be an important prognostic factor for survival of patients diagnosed with laryngeal cancer. When higher zinc levels were correlated with polymorphisms in SOD2 and CAT a further increase in survival was observed.
\end{abstract}

Keywords: laryngeal cancer; zinc; antioxidant enzymes

\section{Introduction}

Laryngeal cancer represents one of the most common head and neck malignancies, accounting for approximately $20 \%$ of all cases, and up to $40 \%$ of patients present with advanced disease at the time of diagnosis [1-3]. The proper treatment for locally advanced laryngeal cancer includes surgery, chemotherapy, radiotherapy, or some combination of these. Regardless of the treatment option, survival in laryngeal cancer patients is poor with 50-70\% 5-year overall survival rates [4]. Given the dismal outcomes for this disease, which have not changed for decades, the identification of modifiable factors, including diet and lifestyle, that could improve prognosis of this fatal disease is necessary. One avenue that warrants interrogation, as it is likely to influence survival, is the role of anti-oxidants in protection from free radicals and how variation in genes involved in this process is associated with disease outcomes.

There are a growing number of studies that have reported that reactive oxygen species (ROS) contribute to various aspects of malignancy, including carcinogenesis, aberrant 
growth, metastasis, and angiogenesis [5]. ROS are chemically reactive molecules containing oxygen, which are generated in cells by certain organelles such as mitochondria or by external factors such as ionizing radiation [6]. ROS are capable of causing lipid peroxidation, altering the activity of antioxidant enzymes which culminate in DNA damage and subsequently genomic instability $[7,8]$. ROS-mediated damage to cellular macromolecules results in deleterious effects associated with carcinogenesis $[9,10]$. The production of ROS and the antioxidant mechanisms remain in dynamic equilibrium such that when ROS levels exceed the antioxidant cell capacity, oxidative stress occurs [11,12]. Antioxidant protection is divided into non-enzymatic and enzymatic mechanisms. The non-enzymatic antioxidants are represented by molecules characterized by the ability to rapidly inactivate free radicals and oxidants [13]. Among them are metal binding proteins, glutathione, uric acid, melatonin, bilirubin, polyamines, vitamins A, E, C, ceruloplasmin and trace metals, e.g., selenium, zinc, copper, iron and manganese [14]. We have previously reported on the influence of serum selenium levels and survival in laryngeal cancer patients [15]. A prospective study of 296 patients undergoing treatment for laryngeal cancer showed that selenium levels in excess of $70 \mu \mathrm{g} / \mathrm{L}$ were associated with improved outcome. This promising result suggested that a correlation between survival in laryngeal cancer patients and the levels of other trace metals involved in antioxidant activity should be investigated.

Zinc is an essential element for human metabolism and is required for multiple biological functions. Zinc is involved in immune function, wound healing, blood clotting, thyroid function and is required for more than 300 different enzymes [16]. Zinc deficiency, which causes increased oxidative stress, leads to a wide range of metabolic diseases, endocrine disorders, developmental imbalances, neurodegenerative problems, immune deficiencies, inflammatory pathologies, skin diseases and wound healing $[17,18]$. Many reports exist between zinc levels and cancer occurrence but to our knowledge little has been reported on disease progression. There have been no studies specifically evaluating the role of circulating zinc and disease prognosis following a diagnosis of laryngeal cancer. Thus, the effect on progression of laryngeal cancer remains unknown.

Enzymatic antioxidant mechanisms consist of an interacting network of antioxidant enzymes, that include superoxide dismutases $(S O D)$, glutathione peroxidases $(G P X)$ and catalases $(C A T)$ [19]. These enzymes break down reactive compounds into oxygen and water, thereby removing free radical damage to a cell. $S O D$ is represented in three forms: $S O D 1$, which is located in the cytoplasm; SOD2, which exists in the mitochondria; and $S O D 3$, which functions in the extracellular matrix. Of these isoforms, SOD2, encoded by the nuclear gene located on chromosome 6q25.3, was found to modify cancer susceptibility, largely due to several functional single nucleotide polymorphisms [20]. The most studied polymorphism is SOD2 47T/C (rs4880), or Val16Ala, which results in the incorporation of either alanine ( $\mathrm{C}$ allele) or valine ( $\mathrm{T}$ allele) in the mitochondrial targeting sequence on the 16th amino acid.

Glutathione peroxidases constitute another major family of antioxidant enzymes. Among eight GPXs expressed in humans, GPX1 is the most abundant and ubiquitous isoform [21]. A polymorphism (rs1050450) GPX1c.599T $>$ C results in the amino acid substitution of leucine ( $\mathrm{T}$ variant) for proline ( $\mathrm{C}$ variant) at position 198 , which results in a decrease in the activity of GPX1 [22,23].

Catalase (CAT) is an important enzyme which can neutralize reactive oxygen species by converting $\mathrm{H}_{2} \mathrm{O}_{2}$ into $\mathrm{H}_{2} \mathrm{O}$ and $\mathrm{O}_{2}$ [24]. A common polymorphism has been identified in the prompter region of $C A T$ c. $262 \mathrm{C}>\mathrm{T}$, rs1001179, which influences transcription factor binding, altering basal transcriptional activity and subsequent expression of this enzyme. Compared with the wild-type allele, the variant $\mathrm{T}$ allele has been linked to lower enzyme activity and increased levels of ROS $[25,26]$.

The goal of the current study was to evaluate whether circulating zinc levels, at the time of diagnosis, and polymorphisms in SOD2, CAT and GPX1 are associated with survival among laryngeal cancer patients. 


\section{Material and Methods}

The current study includes 300 patients treated surgically in the period from July 2009 to February 2017 due to squamous cell carcinoma of the larynx at one University Hospital in Szczecin, Poland within the Pomeranian Medical University. The Otolaryngology Clinic at the University Hospital surgically treats more than $90 \%$ of patients diagnosed with laryngeal cancer in the West Pomeranian region of Poland. The study group accounted for over $70 \%$ of all patients treated for laryngeal cancer in the study period. A pathologic diagnosis of squamous cell laryngeal cancer was confirmed by histopathological review of postoperative material at a single central pathology laboratory in Szczecin. The study was approved by the Ethics Committee of the Pomeranian University of Medicine in Szczecin (KB-0012/167/13; 18 November 2013). All eligible patients provided written informed consent for a blood draw specifically for research purposes and for storage of the blood sample in an existing research biobank. Consenting patients were asked to fast for at least four hours prior to blood collection. A blood sample $(10 \mathrm{~mL})$ was obtained during the diagnostic workup between 8 a.m. and 2 p.m. and was processed within 30 and $120 \mathrm{~min}$ of collection to separate the serum from the cellular fraction. The serum samples were stored at $-80^{\circ} \mathrm{C}$. In November 2017 information on deaths which appeared during the prospective observation period was collected and obtained from the Department of State Infrastructure of the Ministry of Digital Affairs. Death was all-cause mortality because the specific cause of death was not available. The average period of observation for living patients was 62.2 months (min-10, max-101).

Serum zinc levels were measured in the READ-GENE S.A. laboratory using the technique of inductively coupled mass spectroscopy (ICP-MS). Zinc $\left(\mathrm{Zn}^{65}\right)$ concentration in serum samples was measured by inductively coupled plasma mass spectroscopy (ICP-MS) technique using a NexION 350D (PerkinElmer, Shelton, CT, USA) instrument. Zinc was measured in DRC mode with methane $\left(\mathrm{CH}_{4}\right.$, AirProducts, purity $\left.>0.999\right)$ as a reaction gas for removing spectral interferences. To compensate for instrument drift and matrix effects, germanium was set as internal standard. All the reagents were prepared fresh every day. Blank reagent consisted of $0.65 \% \mathrm{HNO}_{3}$ Suprapur Grade (Merck, Darmstadt, Germany), $0.002 \%$ Triton X-100 (PerkinElmer, Shelton, CT, USA) was prepared. Calibration curve standards (100; 200; 500; 1000 and $1500 \mu \mathrm{g} / \mathrm{L})$ were prepared by diluting stock solution of $10 \mathrm{mg} / \mathrm{L}$ Multi-element Calibration Standard 3 (PerkinElmer Pure Plus, Shelton, CT, USA) with blank reagent. An external calibration method was used. The correlation coefficient of the $\mathrm{Zn}$ calibration curve was always greater than 0.999 . Prior to analysis, serum samples were thawed and centrifuged $(7000 \times g \mathrm{rpm}, 15 \mathrm{~min})$ and the supernatant was diluted 100 times with blank reagent and directly measured. ClinChek ${ }^{\circledR}$ Serum Control Level I (Recipe, Munich, Germany) was used as a reference material.

Genotypes of antioxidant enzymes genes were established using real-time PCR with TaqMan probes. The following polymorphism were studied: GPX1 599C/T, rs1050450, Pro198Leu-proline (C variant) replaced with leucine (T variant); SOD2 47T/C, rs4880, Val16Ala-valine (T variant) replaced with alanine (C variant) and CAT 262C/T, rs1001179variant $\mathrm{T}$ allele, which is associated with lower enzyme activity. Polymorphisms in SOD2 and CAT were analyzed using predesigned TaqMan assays and for GPX1 a customized assay was used (primer F: CATTGACATCGAGCCTGACATC; primer R: CACTGCAACTGCCAAGCA; Vic probe: CAGCTGGGCCCTTG; Fam probe: CAGCTGAGCCCTTG). The reaction mix for each sample consisted of TaqMan Genotyping Assay x 40 (Applied Biosystems, Warrington, UK), GoTaq ${ }^{\circledR}$ Probe qPCR Master Mix (Promega, Madison, CA, USA), and deionized water in accordance with the TaqMan Assay manufacturer's instructions. DNA samples and reaction mix were placed in 384-well plates (Axygen, Union City, CA, USA), then real-time PCR reactions were performed on LightCycler ${ }^{\circledR} 480$ (Real-Time PCR System, Roche Diagnostics, Rotkreuz, Switzerland). For genotyping data analysis, LightCycler480 Basic Software Version 1.5 was used (Software release 1.5.0.1.62 SP2; Roche Diagnostics, 2012, USA). 
Statistical analysis. Treatment outcomes were evaluated based on survival time and the number of deaths that occurred during the observation period. The entire group was divided into three subgroups of similar size depending on zinc serum levels. The range of zinc levels determined in this way were used to define subgroups of patients depending on the polymorphisms of oxidative stress enzymes. The relationship between the number of deaths, survival time and the levels of serum zinc was statistically estimated using multivariable Cox proportional hazard models. Multivariable analyses took into account the influence of age, sex, clinical stage, chemotherapy, radiotherapy and pack-years of smoking.

\section{Results}

The characteristics of the 300 laryngeal cancer patients are presented in Table 1 . The mean age of diagnosis was 61 years (range 41 to 82 years). The majority of patients were male (85\%), $96 \%$ had a history of smoking and $42 \%$ were diagnosed with stage IV disease. A total of $45 \%$ of patients received postoperative radiotherapy and $10 \%$ received chemotherapy. A total of 116 patients died during the follow-up period. The average survival time for those who died during the study was 26 months and for the entire cohort was 47.6 months. Overall, the mean serum zinc level was $640.43 \mu \mathrm{g} / \mathrm{L}$ (range $357.76 \mu \mathrm{g} / \mathrm{L}$ to $1317.87 \mu \mathrm{g} / \mathrm{L}$ ) for all participants.

Table 1. Characteristics of the study population $(n=300)$.

\begin{tabular}{|c|c|c|c|}
\hline & & $\begin{array}{c}\text { N (Number of } \\
\text { Patients) }\end{array}$ & $\%$ \\
\hline \multirow{2}{*}{ Sex } & $\mathrm{M}$ (male) & 255 & 85 \\
\hline & $\mathrm{F}$ (female) & 45 & 15 \\
\hline \multirow{2}{*}{ Deceased } & Yes & 116 & 38.7 \\
\hline & No & 184 & 61.3 \\
\hline $\begin{array}{l}\text { Survival time for } \\
\text { participants who died } \\
\text { before the end of the } \\
\text { study period }\end{array}$ & mean, (range) & \multicolumn{2}{|c|}{26 months (2-96) } \\
\hline $\begin{array}{c}\text { Survival time for } \\
\text { entire cohort }\end{array}$ & mean, (range) & \multicolumn{2}{|c|}{47.6 months (2-101) } \\
\hline Age & mean, (range) & \multicolumn{2}{|c|}{$61(41-82)$} \\
\hline $\begin{array}{l}\text { Smoking status } \\
\text { (pack-years) }\end{array}$ & mean, (range) & \multicolumn{2}{|c|}{$37.2(0-150)$} \\
\hline \multirow{2}{*}{ Smoking status } & Yes & 288 & 96 \\
\hline & No & 12 & 4 \\
\hline \multirow{4}{*}{ Stage } & I & 69 & 23 \\
\hline & II & 40 & 13.3 \\
\hline & III & 66 & 22 \\
\hline & IV & 125 & 41.7 \\
\hline \multirow{2}{*}{ Radiotherapy } & Yes & 135 & 45 \\
\hline & No & 165 & 55 \\
\hline \multirow{2}{*}{ Chemotherapy } & Yes & 30 & 10 \\
\hline & No & 270 & 90 \\
\hline Serum zinc level & mean, (range) & \multicolumn{2}{|c|}{$640.43 \mu \mathrm{g} / \mathrm{L}(357.76-1317.87)$} \\
\hline
\end{tabular}

Zinc serum levels appeared to influence survival. Table 2 demonstrates a statistically significant increased risk of death in patients with the lowest zinc levels $(<579 \mu \mathrm{g} / \mathrm{L})$ in 
comparison to patients with the highest levels $(>688 \mu \mathrm{g} / \mathrm{L}$ ): HR (hazard ratio) $=2.32$; CI (confidence interval $)=1.47-3.69 ; p$-value $<0.01$.

Table 2. Serum zinc level and risk of death of patients with laryngeal cancer (entire group, $n=300$ ).

\begin{tabular}{|c|c|c|c|}
\hline \multirow{2}{*}{ Tertiles } & \multirow{2}{*}{$\begin{array}{c}\text { Serum Zinc Level } \\
(\mu \mathrm{g} / \mathrm{L})\end{array}$} & \multicolumn{2}{|c|}{ Number of Patients } \\
\hline & & Dead & Living \\
\hline $\mathrm{ZnA}$ & $357.76-578.71$ & 50 & 49 \\
\hline $\mathrm{ZnB}$ & 579.17-687.98 & 37 & 62 \\
\hline $\mathrm{ZnC}$ & $688.54-1317.87$ & 29 & 73 \\
\hline
\end{tabular}

Cox Regression

$\mathrm{ZnB}(37$ and 62) vs. $\mathrm{ZnC}(29$ and 73) $\mathrm{HR}=1.43 ; \mathrm{CI}=0.88-2.34 ; p$-value $=0.145$

$\mathrm{ZnA}$ (50 and 49) vs. $\mathrm{ZnC}(29$ and 73) $\mathrm{HR}=2.32 ; \mathrm{CI}=1.47-3.69 ; p$-value $<0.01$

Table 3 summarizes the multivariable hazard ratios (HR) and associated confidence intervals for various factors on overall survival. Only the relationship between cancer stage $(p<0.01)$ and zinc levels $(p<0.01)$ remained significant in the multivariate model. Compared to tertile $\mathrm{C}$ (reference, highest zinc serum level), the HR for tertile A (lowest zinc level) was $1.95(\mathrm{CI}=1.21-3.17)$.

Table 3. Multivariable Cox regression (entire group, $n=300$ ).

\begin{tabular}{|c|c|c|c|c|}
\hline \multicolumn{2}{|c|}{ Feature } & \multirow{2}{*}{$\begin{array}{c}\text { HR } \\
1.956\end{array}$} & \multirow{2}{*}{$\begin{array}{c}\text { CI (2.5-97.5\%) } \\
1.21-3.17\end{array}$} & \multirow{2}{*}{$\begin{array}{c}p \text {-Value } \\
<0.01\end{array}$} \\
\hline \multirow{3}{*}{ Serum zinc level } & A & & & \\
\hline & B & 1.344 & $0.82-2.21$ & 0.245 \\
\hline & $\mathrm{C}$ & 1.0 & & \\
\hline \multirow{2}{*}{ Sex } & $\mathrm{F}$ & 1.0 & - & - \\
\hline & $\mathrm{M}$ & 0.668 & $0.4-1.12$ & 0.127 \\
\hline \multirow{4}{*}{ Clinical stage } & I & 1.0 & - & - \\
\hline & II & 2.33 & $0.93-5.83$ & 0.07 \\
\hline & III & 2.23 & $0.98-5.07$ & 0.056 \\
\hline & IV & 7.304 & $3.28-16.26$ & $<0.01$ \\
\hline \multirow{2}{*}{ Chemotherapy } & Yes & 0.802 & $0.43-1.51$ & 0.494 \\
\hline & No & 1.0 & - & - \\
\hline \multirow{2}{*}{ Radiotherapy } & Yes & 1.197 & $0.73-1.96$ & 0.473 \\
\hline & No & 1.0 & - & - \\
\hline Pack-years & & 1.011 & $1-1.02$ & 0.069 \\
\hline \multirow{2}{*}{ Age } & $\leq 60$ & 1.0 & - & - \\
\hline & $>60$ & 1.37 & $0.92-2.04$ & 0.122 \\
\hline \multirow{2}{*}{ GPX1 } & $\mathrm{TC} / \mathrm{TT}$ & 0.987 & $0.67-1.44$ & 0.945 \\
\hline & $\mathrm{CC}$ & 1.0 & & \\
\hline \multirow{2}{*}{ SOD2 } & $\mathrm{TC} / \mathrm{TT}$ & 1.042 & $0.68-1.59$ & 0.847 \\
\hline & $\mathrm{CC}$ & 1.0 & & \\
\hline \multirow{2}{*}{$C A T$} & $\mathrm{TC} / \mathrm{TT}$ & 1.09 & $0.74-1.6$ & 0.661 \\
\hline & $\mathrm{CC}$ & 1.0 & & \\
\hline
\end{tabular}

Polymorphisms of antioxidant genes by themselves were not correlated with survival using the multivariate model. However the zinc influence on survival was different 
depending on the genotypes of the antioxidant enzymes. The polymorphism GPX1 TC/TT was present in $128(42.6 \%)$ and GPX1 CC in $172(57.4 \%)$ patients. There was no statistically significant difference in zinc impact on survival between these polymorphism subgroups. For both variants the risk of death was increased in patients with the lowest zinc levels in comparison to patients with the highest levels: $\mathrm{HR}=2.32(\mathrm{CI}=1.08-5.01 ; p=0.03)$ for GPX1 TC/TT and HR $=1.93(\mathrm{CI}=1.01-3.71 ; p=0.047)$ for the GPX1 CC variant (Table 4). From these results it appears the GPX1 polymorphism does not influence the effect of zinc on the survival of patients with laryngeal cancer.

Table 4. Impact on survival of zinc serum level depending on GPX1 polymorphism (multivariable Cox regression).

\begin{tabular}{|c|c|c|c|c|c|c|}
\hline \multicolumn{3}{|c|}{ GPX1 TC/TT $(\mathrm{n}=128)$} & & \multicolumn{3}{|c|}{ GPX1 CC $(\mathrm{n}=172)$} \\
\hline \multirow{2}{*}{ Tertiles } & \multicolumn{2}{|c|}{ Number of Patients } & \multirow{6}{*}{ vs. } & \multirow{2}{*}{ Tertiles } & \multicolumn{2}{|c|}{ Number of Patients } \\
\hline & Dead & Living & & & Dead & Living \\
\hline $\mathrm{ZnA}$ & 28 & 16 & & $\mathrm{ZnA}$ & 22 & 33 \\
\hline $\mathrm{ZnB}$ & 16 & 29 & & $\mathrm{ZnB}$ & 21 & 33 \\
\hline $\mathrm{ZnC}$ & 10 & 29 & & $\mathrm{ZnC}$ & 19 & 44 \\
\hline \multicolumn{3}{|c|}{$\begin{aligned} \text { ZnB vs. } \mathrm{ZnC} \mathrm{HR} & =1.13 ; \mathrm{CI}=0.5-2.59 \\
p & =0.76 \\
\text { ZnA vs. } \mathrm{ZnC} \mathrm{HR} & =2.32 ; \mathrm{CI}=1.08-5.01 \\
p & =0.03\end{aligned}$} & & \multicolumn{3}{|c|}{$\begin{array}{c}\text { ZnB vs. } \mathrm{ZnC} H \mathrm{HR}=1.66 ; \mathrm{CI}=0.88-3.14 ; \\
p=0.118 \\
\text { ZnA vs. } \mathrm{ZnC} \mathrm{HR}=1.93 ; \mathrm{CI}=1.01-3.71 ; \\
p=0.047\end{array}$} \\
\hline
\end{tabular}

With respect to the SOD2 genotypes, only for the subgroup of SOD2 TC/TT patients (219 patients, 73\%) was the influence of serum zinc levels on survival statistically significant. For SOD2 TC/TT variant carriers the risk of death was increased in patients with the lowest zinc levels in comparison with patients with the highest levels: $\mathrm{HR}=3.0 ; \mathrm{CI}=1.63-5.55$; $p$-value $<0.01$ and for SOD2 CC variant there was no statistically significant difference: $\mathrm{HR}=0.83 ; \mathrm{CI}=0.33-2.14 ; p$-value $=0.70$ (Table 5).

Table 5. Impact on survival of zinc serum level depending on SOD2 polymorphism (multivariable Cox regression).

\begin{tabular}{|c|c|c|c|c|c|c|}
\hline \multicolumn{3}{|c|}{ SOD2 TC/TT $(\mathrm{n}=219)$} & & \multicolumn{3}{|c|}{ SOD2 CC $(\mathrm{n}=81)$} \\
\hline \multirow{2}{*}{ Tertiles } & \multicolumn{2}{|c|}{ Number of Patients } & \multirow{6}{*}{ vs. } & \multirow{2}{*}{ Tertiles } & \multicolumn{2}{|c|}{ Number of Patients } \\
\hline & Dead & Living & & & Dead & Living \\
\hline $\mathrm{ZnA}$ & 42 & 37 & & $\mathrm{ZnA}$ & 8 & 12 \\
\hline $\mathrm{ZnB}$ & 26 & 49 & & $\mathrm{ZnB}$ & 11 & 13 \\
\hline $\mathrm{ZnC}$ & 16 & 49 & & $\mathrm{ZnC}$ & 13 & 24 \\
\hline \multicolumn{3}{|c|}{$\begin{array}{c}\mathrm{ZnB} \text { vs. } \mathrm{ZnC} \mathrm{HR}=1.60 ; \mathrm{CI}=0.85-3.03 ; \\
p=0.144 \\
\text { ZnA vs. } \mathrm{ZnC} \mathrm{HR}=3.0 ; \mathrm{CI}=1.63-5.55 ; \\
p<0.01\end{array}$} & & \multicolumn{3}{|c|}{$\begin{aligned} \text { ZnB vs. } Z \mathrm{nC} \mathrm{HR} & =0.70 ; \mathrm{CI}=0.28-1.77 ; \\
p & =0.46 \\
\mathrm{ZnA} \text { vs. } \mathrm{ZnC} \mathrm{HR} & =0.83 ; \mathrm{CI}=0.33-2.14 ; \\
p & =0.70\end{aligned}$} \\
\hline
\end{tabular}

In subgroup of $C A T C C$ patients (162 patients, $54 \%$ ) the influence of serum zinc levels on survival was stronger and statistically significant compared to CAT TC/TT patients. For the CAT CC variant the risk of death was increased in patients with the lowest zinc levels in comparison with patients with the highest levels: $\mathrm{HR}=2.55 ; \mathrm{CI}=1.32-4.97 ; p$-value $<0.01$ and for $C A T T C / T T$ variant there was no statistically significant difference $(\mathrm{HR}=1.71$; $\mathrm{CI}=0.85-3.44 ; p$-value $=0.129)($ Table 6$)$. 
Table 6. Impact on survival of zinc serum level depending on CAT polymorphism (multivariable Cox regression).

\begin{tabular}{|c|c|c|c|c|c|c|}
\hline \multicolumn{3}{|c|}{$C A T C C(\mathrm{n}=162)$} & & \multicolumn{3}{|c|}{$C A T T C / T T(\mathrm{n}=138)$} \\
\hline \multirow{2}{*}{ Tertiles } & \multicolumn{2}{|c|}{ Number of Patients } & \multirow{6}{*}{ vs. } & \multirow{2}{*}{ Tertiles } & \multicolumn{2}{|c|}{ Number of Patients } \\
\hline & Dead & Living & & & Dead & Living \\
\hline $\mathrm{ZnA}$ & 24 & 25 & & $\mathrm{ZnA}$ & 24 & 26 \\
\hline $\mathrm{ZnB}$ & 17 & 41 & & $\mathrm{ZnB}$ & 21 & 20 \\
\hline $\mathrm{ZnC}$ & 15 & 40 & & $\mathrm{ZnC}$ & 14 & 33 \\
\hline \multicolumn{3}{|c|}{$\begin{array}{c}\text { ZnB vs. } \mathrm{ZnC} \mathrm{HR}=1.15 ; C I=0.56-2.39 ; \\
p=0.692 \\
\text { ZnA vs. ZnC HR=2.55; CI }=1.32-4.97 ; \\
p<0.01\end{array}$} & & \multicolumn{3}{|c|}{$\begin{array}{c}\text { ZnB vs. } \mathrm{ZnC} \mathrm{HR=1.75;CI}=0.85-3.64 ; \\
p=0.129 \\
\text { ZnA vs. } \mathrm{ZnC} \mathrm{HR=1.71;CI}=0.85-3.44 ; \\
p=0.129\end{array}$} \\
\hline
\end{tabular}

Taking into account the results presented in Tables 4-6, the influence of zinc on survival is strongly influenced for patients carrying the SOD2 TC/TT and CAT CC variants. Given only those variants, the serum zinc level impact on the risk of death was stronger compared with the entire cohort. For a subgroup of patients with at least one of the variants present (SOD2 TC/TT or CAT CC (260 patients, 86\%)) the HR with the lowest zinc levels group (A) was $2.5(\mathrm{CI}=1.48-4.21, p<0.01)$ compared with those patients from the highest zinc level group (C) (Table 7).

Table 7. Multivariable Cox regression $\left(\mathrm{SOD}_{2} \mathrm{TC} / \mathrm{TT}\right.$ or $\left.C A T C C, \mathrm{n}=260\right)$.

\begin{tabular}{|c|c|c|c|c|}
\hline \multicolumn{2}{|c|}{ Feature } & \multirow{2}{*}{\begin{tabular}{|c|} 
HR \\
2.497
\end{tabular}} & \multirow{2}{*}{$\begin{array}{c}\text { CI (2.5-97.5\%) } \\
1.48-4.21\end{array}$} & \multirow{2}{*}{$\begin{array}{c}p \text {-Value } \\
<0.01\end{array}$} \\
\hline & A & & & \\
\hline Serum zinc level & B & 1.318 & $0.76-2.28$ & 0.324 \\
\hline & $\mathrm{C}$ & 1.0 & & \\
\hline \multirow{2}{*}{ Sex } & $\mathrm{F}$ & 1.0 & & \\
\hline & $\mathrm{M}$ & 0.72 & $0.42-1.24$ & 0.238 \\
\hline \multirow{4}{*}{ Clinical stage } & I & 1.0 & & \\
\hline & II & 2.379 & $0.9-6.29$ & 0.08 \\
\hline & III & 2.207 & $0.93-5.25$ & 0.073 \\
\hline & IV & 5.916 & $2.54-13.77$ & $<0.01$ \\
\hline \multirow{2}{*}{ Chemotherapy } & Yes & 0.792 & $0.41-1.53$ & 0.488 \\
\hline & No & 1.0 & & \\
\hline \multirow{2}{*}{ Radiotherapy } & Yes & 1.628 & $0.96-2.76$ & 0.071 \\
\hline & No & 1.0 & & \\
\hline Pack-years & & 1.009 & $1-1.02$ & 0.147 \\
\hline \multirow{2}{*}{ Age } & $\leq 60$ & 1.0 & & \\
\hline & $>60$ & 1.205 & $0.79-1.84$ & 0.39 \\
\hline
\end{tabular}

Impact of serum zinc levels on the risk of death in laryngeal cancer patients was multiplied in the subgroup with a combined positive antioxidant enzymes polymorphism profile resulting in a positive influence on survival. In the subgroup combining polymorphisms of SOD2 TC/TT and CAT CC (121 patients, 40.3\%) the HR for the lowest zinc level tertile (A) was $3.13(\mathrm{CI}=1.32-7.46 ; p$-value $=0.01)$ compared with highest zinc level tertile $(\mathrm{C})$ (Table 8). 
Table 8. Multivariable Cox regression (SOD2 TC/TT and CAT CC, $\mathrm{n}=121$ ).

\begin{tabular}{|c|c|c|c|c|}
\hline \multicolumn{2}{|c|}{ Feature } & \multirow{2}{*}{$\begin{array}{c}\text { HR } \\
3.134\end{array}$} & \multirow{2}{*}{$\begin{array}{c}\text { CI (2.5-97.5\%) } \\
1.32-7.46\end{array}$} & \multirow{2}{*}{$\begin{array}{c}p \text {-Value } \\
0.01\end{array}$} \\
\hline & $\mathrm{A}$ & & & \\
\hline Serum zinc level & B & 1.446 & $0.57-3.69$ & 0.44 \\
\hline & $\mathrm{C}$ & 1.0 & & \\
\hline \multirow{2}{*}{ Sex } & $\mathrm{F}$ & 1.0 & & \\
\hline & M & 0.707 & $0.31-1.63$ & 0.415 \\
\hline \multirow{4}{*}{ Clinical stage } & I & 1.0 & & \\
\hline & II & 3.812 & $0.82-17.81$ & 0.089 \\
\hline & III & 3.178 & $0.75-13.51$ & 0.117 \\
\hline & IV & 15.246 & $3.83-60.72$ & $<0.01$ \\
\hline \multirow{2}{*}{ Chemotherapy } & Yes & 0.238 & $0.07-0.84$ & 0.026 \\
\hline & No & 1.0 & & \\
\hline \multirow{2}{*}{ Radiotherapy } & Yes & 1.33 & $0.59-2.98$ & 0.49 \\
\hline & No & 1.0 & & \\
\hline Pack-years & & 1.003 & $0.98-1.02$ & 0.718 \\
\hline \multirow{2}{*}{ Age } & $\leq 60$ & 1.0 & & \\
\hline & $>60$ & 1.11 & $0.57-2.17$ & 0.761 \\
\hline
\end{tabular}

On the other hand, in the subgroup of patients in whom neither the SOD2 TC/TT nor CAT CC variant was found, the effect of zinc on survival was the opposite. The HR for the lowest zinc level tertile $(\mathrm{A})$ was $0.40(\mathrm{CI}=0.08-1.98$; $p$-value $=0.266)$ compared with highest zinc level tertile (C); however, due to the small size of the group $(n=40)$, the difference was not statistically significant (Table 9).

Table 9. Multivariable Cox regression (without SOD2 TC/TT and without $C A T C C, \mathrm{n}=40$ ).

\begin{tabular}{|c|c|c|c|c|}
\hline \multicolumn{2}{|c|}{ Feature } & \multirow{2}{*}{$\begin{array}{c}\text { HR } \\
0.409\end{array}$} & \multirow{2}{*}{$\begin{array}{c}\text { CI (2.5-97.5\%) } \\
0.08-1.98\end{array}$} & \multirow{2}{*}{$\begin{array}{c}p \text {-Value } \\
0.266\end{array}$} \\
\hline & $\mathrm{A}$ & & & \\
\hline Serum zinc level & B & 0.447 & $0.07-2.88$ & 0.397 \\
\hline & $\mathrm{C}$ & 1.0 & & \\
\hline \multirow{2}{*}{ Sex } & $\mathrm{F}$ & 1.0 & & \\
\hline & $M$ & 0.291 & $0.03-2.74$ & 0.28 \\
\hline \multirow{4}{*}{ Clinical stage } & I & 1.0 & & \\
\hline & II & 3.752 & $0.21-67.48$ & 0.37 \\
\hline & III & 1.212 & $0.07-20.82$ & 0.894 \\
\hline & IV & 142.487 & $6.16-3293.38$ & $<0.01$ \\
\hline \multirow{2}{*}{ Chemotherapy } & Yes & 0.826 & $0.08-8.92$ & 0.875 \\
\hline & No & 1.0 & & \\
\hline \multirow{2}{*}{ Radiotherapy } & Yes & 0.061 & $0.01-0.44$ & $<0.01$ \\
\hline & No & 1.0 & & \\
\hline Pack-years & & 1.056 & $1.01-1.1$ & $<0.01$ \\
\hline \multirow{2}{*}{ Age } & $\leq 60$ & 1.0 & & \\
\hline & $>60$ & 2.958 & $0.58-15.15$ & 0.193 \\
\hline
\end{tabular}




\section{Discussion}

The results from this study suggest that low levels of serum zinc at the time of diagnosis are associated with a significantly increased risk of death among laryngeal cancer patients who reside in Szczecin, Poland. The effect appeared to be continuous; that is, the risk of death declined continuously with increasing circulating levels of zinc and there was no apparent threshold value. Individuals in the lowest tertile of zinc had a 1.95-fold increased risk of dying during their follow-up period.

Many reports exist regarding the zinc levels in cancer versus the corresponding normal tissues. Decreased levels of zinc in malignant tissues have been shown for pancreatic, hepatocellular, prostate, lung, colon, thyroid, kidney, gall bladder and ovarian cancers [27-35]. Decreased levels of zinc in cancers have been shown in malignant tissue and in other specimens such as serum, hair and nails. Analysis of the serum zinc levels has revealed a tendency toward an increased risk of breast cancer for unselected breast cancers and among BRCA1 carriers with low zinc levels [36].

There have been few studies evaluating the correlation between zinc levels and the occurrence of head and neck cancers. Abdulla et al. have shown that zinc in plasma and whole blood from 13 patients with squamous cell carcinoma of the head and neck was significantly lower than in healthy controls [37]. Wozniak reported decreased levels of zinc in hair and nails in a group of 59 patients with larynx, salivary gland, oral cavity and tongue cancers [38]. A study by Varghese revealed that there was a significant reduction in the serum zinc levels in both oral cavity leucoplakia and cancer in the cohort of 100 patients [39]. Other authors have published contrary results. Most recently, a study by Golasik, on the Polish population, revealed a decreased level of zinc in hair but an increase in serum in 66 laryngeal cancer patients compared with healthy controls [40]. Similar observations on increased levels of serum zinc in cancer patients, among them head and neck malignancies, was reported by Pasha [41].

Several studies have examined zinc status and cancer mortality. Data from a French cohort study and the National Health and Nutrition Examination Survey (NHANES) have linked lower zinc levels with increased overall cancer mortality [42]. Similar results have been shown for the US population [43]. In contrast it was reported that serum zinc levels may be not associated with hepatocellular cancer survival [44]. Until now, there has been very limited evidence for a role of zinc status on laryngeal cancer progression or outcome. Abdulla reported that serum zinc was significantly lower in head and neck cancer patients who did not respond to therapy and who died within 12 months compared to those who responded to therapy and had a remission within 12-15 months [37]. To our knowledge, there are no studies that have specifically evaluated the relationship between zinc levels and disease prognosis in laryngeal cancer.

The reference level of $\mathrm{Zn}$ in serum is $600-1200 \mu \mathrm{g} / \mathrm{L}$ [45]. The prevalence rate of inadequate zinc levels for the general population of Central and Eastern Europe is about $10 \%$ [46]. In our cohort, 118 patients had serum zinc levels below the reference level (39.3\%). The best prognosis was observed in the tertile with zinc levels above $688 \mu \mathrm{g} / \mathrm{L}$.

Zinc deficiency may lead to a wide range of metabolic diseases, endocrine disorders, developmental imbalances, neurodegenerative problems, immune deficiencies, inflammatory pathologies, skin diseases and poor wound healing [17,18]. Zinc is reported to induce apoptosis and cytotoxicity in different tumor types including prostate, ovarian, hepatocellular, pancreatic and breast cancers [47-49]. The exact mechanisms underlying this synergism and zinc-induced apoptosis are unclear, but zinc homeostasis and p53 functions appear to be key factors for subsequent physiological processes including DNA repair, cell cycle regulation and response to oxidative stress [50]. Intracellular zinc deficiency can enhance DNA damage due to oxidative stress and also blocks critical cellular signals that drive DNA repair and apoptosis. Zinc deficiency results in increased sensitivity to oxidative stress, increased DNA damage and accelerated carcinogenesis [51]. A study by Jayaraman demonstrated that exposure of pancreatic cancer cells to zinc leads to increased protein degradation and enhanced cell death, proposing zinc as a potential therapy in the treatment 
of pancreatic cancer [52]. Kocdor reported that zinc supplementation induces apoptosis and enhances antitumor efficacy of docetaxel in non-small-cell lung cancer [53]. Other authors suggest that zinc has the potential to be developed as either a primary treatment or as a second line of defense against ovarian cancers that have developed resistance to currently used chemotherapeutics [54].

Several large observational cohort studies have found that dietary zinc intakes are inversely associated with cancer occurrence and all-cause mortality risks. It was shown that the use of zinc supplements was associated with reduced prostate cancer risk [55]. The Vitamins And Lifestyle cohort study found that, although long-term use of zinc supplements was not associated with reduced prostate cancer risk, it was associated with a reduced risk for advanced prostate cancer [56]. A study from Sweden clearly showed that high dietary zinc intake was associated with a reduced risk for prostate cancer-specific mortality [57].

To our knowledge no studies have been reported for laryngeal cancer. According to data provided on other cancers and the results of our study, zinc supplementation might improve the prognosis in laryngeal cancer patients. However, it is too early to tell from these observations that the association between serum zinc and survival is causal or if the effect of low zinc can be mitigated by zinc supplementation and future studies are required to determine if zinc has therapeutic benefit in this setting.

In our study we examined the most common polymorphisms of antioxidant genes: (1) SOD2 47T/C, rs4880, Val16Ala; (2) CAT 262C/T, rs1001179; (3) GPX1 599C/T, rs1050450, Pro198Leu. We found that these variants by themselves were not correlated with prognosis of laryngeal cancer patients. However, serum zinc level impact on survival in laryngeal cancer patients was influenced by genotypes of SOD2 and CAT. SOD2 TC/TT and CAT CC were found to be "positive" variants in which zinc serum levels had the strongest correlation with survival. In subgroups with SOD2 CC and CAT TC/TT there was no statistically significant correlation between zinc serum level and survival. GPX1 polymorphism did not change the effect of zinc levels on survival.

SOD2 47T/C (rs4880) polymorphism or Val16Ala results in the incorporation of either alanine ( $\mathrm{C}$ allele) or valine ( $\mathrm{T}$ allele) in the mitochondrial targeting sequence. Experimental data indicate that the Ala containing SOD2 is targeted into the mitochondria, whereas the Val form of the protein is partially arrested in the inner mitochondrial membrane [58]. The less efficient form (T) would be associated with higher levels of ROS and greater risk of cancer. In numerous studies, the variant $C$ allele was observed as a risk factor for breast cancer [59,60], prostate cancer [61], gastric cancer [62], lung cancer [63], acoustic neuroma [64], hepatocellular cancer [65] and ovarian cancer [66]. SOD2 expression can also impact cancer progression. Cases with higher SOD2 activity of the tumor were associated with worse overall survival in renal cell cancer patients [67] as well as occurrence of distant metastasis and reduced survival in salivary adenoid cystic cancer [68] and gastric cancer [69]. Reduced expression of SOD2 was correlated with poorer survival of patients with aggressive thyroid or adrenal cancers [70]. Little is known about SOD2 polymorphism on cancer survival. The CC genotype was shown to be associated with reduced risk of death after treatment for breast cancer [71] and no correlation with prognosis was found for gastric cancer [72]. In our study, TC/TT variant carriers, which theoretically are a less efficient form, were found to be positively correlated with zinc impact on survival.

In the case of CAT262C/T (rs1001179) polymorphism, compared with the C allele, the variant $\mathrm{T}$ allele has been associated with lower enzyme activity and consequently increased levels of ROS [25,26]. The results of association studies of this polymorphism with cancer risk remain inconsistent and inconclusive. The TT genotype was demonstrated to be a risk factor for breast cancer [26] and prostate cancer in men diagnosed aged $<65$ [73]. In prostate cancer the TT genotype increased the risk for high-stage disease and metastasis, respectively, implying that this polymorphism may also be a risk factor in tumor progression and metastasis [20]. Studies on breast cancer patients suggest that TT 
genotype is associated with reduced risk of death [71] or has no impact on survival [74]. In our study, zinc had stronger influence on survival in cases of the more active CC variant.

The presence of the GPX1 $\mathrm{T}$ variant allele contributes to an increased risk of melanoma [75] and meningioma [76]. However, the $\mathrm{T}$ variant has also been shown to have a protective role in reducing the occurrence of colorectal adenocarcinoma [77]. In cases of lung and breast cancer, opposing results were shown with the $\mathrm{T}$ variant increasing $[78,79]$ as well as decreasing $[23,80]$ the risk. For other malignancies such as gastric, hepatocellular, pancreatic, prostate and bladder cancer no correlation between occurrence risk and polymorphism was found [81-85]. The role of GPX1 in cancer survival remains uncertain. Most studies suggest that high expression of GPX1 in tumor tissue is correlated with worse survival. This was shown for lung cancer [86], oral cavity cancer [87] and laryngeal cancer [88]. Other data have shown that expression of GPX1 has no prognostic significance in head and neck cancers, however in advanced T3/4 tumors the expression was lower compared to T1/2 tumors [89]. Polymorphism in GPX1 gene had no impact on survival in studies concerning breast [74] and gastric cancer [90]. The influence of the polymorphism itself on the level of GPX1 activity is not unequivocal, however most authors agree that the $\mathrm{T}$ variant (Leu) leads to decreased enzyme activity. According to some authors, the catalytic activity of a protein decreases by $5 \%$ with each additional copy of the altered allele [22,23,78,91]. In our study, GPX1 polymorphism did not change the effect of zinc levels on the survival. In both variants the risk of death was increased in patients with the lowest zinc levels in comparison to patients with the highest levels, however for TC/TT variant carriers (i.e., less efficient form), the correlation with zinc on survival was slightly stronger (HR- 2.32 for TC/TT and 1.93 for CC variant).

Molecular mechanisms that would explain the positive effect of zinc on the survival of patients with laryngeal cancer, only in cases of certain antioxidant enzyme polymorphisms, remain unknown and cannot be explained on the basis of the knowledge available in the literature. Further research is needed in this area. However, the results of our research show that the interaction of enzymatic and non-enzymatic (zinc) antioxidant mechanisms is essential for the survival of patients with laryngeal cancer. It is particularly evident in the subgroup combining both "positive" variants, SOD2 TC/TT and CAT CC, which results in strong dependence between survival and zinc serum level with $H R=3.13$. This combination was present in $40 \%$ of patients. At least one positive variant was present in $86 \%$ of patients with survival dependent on serum zinc level with $\mathrm{HR}=2.55$. These results suggest that zinc supplementation in those patients could have positive effect on survival. On the other hand, $13 \%$ of patients had neither the SOD2 TC/TT nor CAT CC variant and in that particular subgroup zinc influence on survival seemed to be the opposite, suggesting that those patients should be excluded from zinc supplementation. This result, due to the small size of the group, was not statistically significant and further research on larger, neither the SOD2 TC/TT nor CAT CC, group is needed to confirm this tendency.

The strengths of our study include the large number of patients identified from one institution and the use of fasting blood samples for zinc measurement. We performed a multivariate analyses taking into account the influence of age, sex, clinical stage, chemotherapy, radiotherapy and pack-years. Despite this, our study was not without limitations. Zinc levels were taken after diagnosis and it is possible that the cancer might have influenced the level. Zinc was measured only once and serum levels tend to fluctuate which may account for minor differences in the population under study. Because of limitations in the data in the Polish vital statistics data base we used all-cause mortality as an endpoint. We expect the majority of the deaths (but not all) in this study are due to laryngeal cancer. By using all-cause mortality, we may have underestimated the effect on laryngeal cancer-specific mortality. The individual subgroups were small and it is difficult to compare the effects of zinc in various subgroups. 


\section{Conclusions}

The level of zinc in the serum is an important prognostic factor in laryngeal cancer. The influence of serum zinc levels on survival in laryngeal cancer patients can be multiplied if correlated with adequate antioxidant enzymes polymorphisms: SOD2 TC/TT and CAT CC. A total of $86 \%$ of all laryngeal cancer patients have at least one of those genotypes, suggesting survival is dependent on serum zinc level with a HR of $2.55 ; 40 \%$ have both, with a HR of 3.13. Zinc supplementation in those patients might have positive effect on survival. A total of $13 \%$ of patients have neither the SOD2 TC/TT nor CAT CC variant and in that particular subgroup zinc influence on survival seems to be the opposite, suggesting that those patients should be excluded from zinc supplementation.

\section{Patent}

The described discovery in this paper has been covered by Polish patent application owned by Pomeranian Medical University (P.427370).

Author Contributions: Conceptualization: J.L. and J.A.L.; Methodology: J.L. and J.A.L.; Software: P.B. and W.M.; Validation: J.A.L., E.J. and R.J.S.; Formal Analysis: J.A.L. and P.B.; Investigation: J.L. and E.J.; Resources: J.L. and R.D.; Data Curation: J.L. and R.D. and K.B.; Writing-Original Draft Preparation: J.L., W.M. and K.B.; Writing-Review and Editing: J.L., J.A.L. and R.J.S.; Visualization: J.L.; Supervision: J.A.L. and E.J.; Project Administration: J.L.; Funding Acquisition: J.L. All authors have read and agreed to the published version of the manuscript.

Funding: This research was funded by Mini Grant "INNOVATION INCUBATOR+"-based on the European Regional Development Fund, project title: Diagnostic test for the prognosis of survival of patients with laryngeal cancer based on the assessment of selenium and heavy metals levels in blood and serum, contract number and date: MNISW/2017/DIR/72 9 March 2017.

Institutional Review Board Statement: The study was conducted according to the guidelines of the Declaration of Helsinki, and approved by the Ethics Committee of Pomeranian Medical University (KB-0012/167/13; 18 November 2013).

Informed Consent Statement: Informed consent was obtained from all subjects involved in the study.

Data Availability Statement: Data supporting reported results are available from the first author to all interested researchers.

Acknowledgments: We thank E Putresza and G Sukiennicki for their technical support.

Conflicts of Interest: Jan Lubiński (last author) is CEO of ReadGene which offers measurement of selenium and heavy metals levels. These authors are employees of ReadGene: Róża Derkacz and Wojciech Marcinik. Jakub Lubiński (first author), Ewa Jaworowska, Katarzyna Białkowska, Piotr Baszuk and Rodney Scott declare no conflict of interest. This study was conducted at Pomeranian Medical University.

\section{References}

1. Hoffman, H.T.; Karnell, L.H.; Funk, G.F.; Robinson, R.A.; Menck, H.R. The National Cancer Data Base report on cancer of the head and neck. Arch. Otolaryngol. Head Neck Surg. 1998, 124, 951-962. [CrossRef] [PubMed]

2. Chu, E.A.; Kim, Y.J. Laryngeal Cancer: Diagnosis and Preoperative Work-up. Otolaryngol. Clin. N. Am. 2008, 41, 673-695. [CrossRef]

3. Siegel, R.; Ma, J.; Zou, Z.; Jemal, A. Cancer statistics, 2014. CA Cancer J. Clin. 2014, 64, 364. [CrossRef]

4. Patel, T.D.; Echanique, K.A.; Yip, C.; Hsueh, W.D.; Baredes, S.; Park, R.C.W.; Eloy, J.A. Supraglottic Squamous Cell Carcinoma: A Population-Based Study of 22,675 Cases. Laryngoscope 2019, 129, 1822-1827. [CrossRef] [PubMed]

5. Nishikawa, M. Reactive oxygen species in tumor metastasis. Cancer Lett. 2008, 266, 53-59. [CrossRef]

6. Muller, F. The nature and mechanism of superoxide production by the electron transport chain: Its relevance to aging. J. Am. Aging Assoc. 2000, 23, 227-253. [CrossRef] [PubMed]

7. Cooke, M.S.; Evans, M.D.; Dizdaroglu, M.; Lunec, J. Oxidative DNA damage: Mechanisms, mutation, and disease. FASEB J. 2003, 17, 1195-1214. [CrossRef] [PubMed]

8. Dargel, R. Lipid peroxidation-A common pathogenetic mechanism? Exp. Toxicol. Pathol. 1992, 44, 169-181. [CrossRef]

9. Sarsour, E.H.; Kumar, M.G.; Chaudhuri, L.; Kalen, A.L.; Goswami, P.C. Redox Control of the Cell Cycle in Health and Disease. Antioxid. Redox Signal. 2009, 11, 2985-3011. [CrossRef] [PubMed] 
10. Costa, A.; Scholer-Dahirel, A.; Mechta-Grigoriou, F. The role of reactive oxygen species and metabolism on cancer cells and their microenvironment. Semin. Cancer Biol. 2014, 25, 23-32. [CrossRef] [PubMed]

11. Morel, Y.; Barouki, R. Repression of gene expression by oxidative stress. Biochem. J. 1999, 342, 481-496. [CrossRef] [PubMed]

12. Al-Gadani, Y.; El-Ansary, A.; Attas, O.; Al-Ayadhi, L. Metabolic biomarkers related to oxidative stress and antioxidant status in Saudi autistic children. Clin. Biochem. 2009, 42, 1032-1040. [CrossRef] [PubMed]

13. Mironczuk-Chodakowska, I.; Witkowska, A.M.; Zujko, M.E. Endogenous non-enzymatic antioxidants in the human body. Adv. Med. Sci. 2018, 63, 68-78. [CrossRef]

14. Gałecka, E.; Mrowicka, M.; Malinowska, K.; Gałecki, P. Chosen non-enzymatic substances that participate in a protection against overproduction of free radicals. Pol. Merkur. Lek. 2008, 25, 269-272.

15. Lubiński, J.; Marciniak, W.; Muszynska, M.; Jaworowska, E.; Sulikowski, M.; Jakubowska, A.; Kaczmarek, K.; Sukiennicki, G.; Falco, M.; Baszuk, P.; et al. Serum selenium levels and the risk of progression of laryngeal cancer. PLoS ONE 2018, 13, e0184873. [CrossRef] [PubMed]

16. Prasad, A.S. Zinc: An overview. Nutrition 1995, 11 (Suppl. 1), 93-99. [PubMed]

17. Maret, W.; Sandstead, H.H. Zinc requirements and the risks and benefits of zinc supplementation. J. Trace Elem. Med. Biol. 2006, 20, 3-18. [CrossRef]

18. Fabris, N.; Mocchegiani, E. Zinc, human diseases and aging. Aging 1995, 7, 77-93. [CrossRef] [PubMed]

19. Yuzhalin, A.E.; Kutikhin, A.G. Inherited variations in the SOD and GPX gene families and cancer risk. Free Radic. Res. 2012, 46, 581-599. [CrossRef]

20. Tefik, T.; Kucukgergin, C.; Sanli, O.; Oktar, T.; Seckin, S.; Ozsoy, C. Manganese superoxide dismutase Ile58Thr, catalase C-262T and myeloperoxidase G-463A gene polymorphisms in patients with prostate cancer: Relation to advanced and metastatic disease. BJU Int. 2013, 112, E406-E414. [CrossRef] [PubMed]

21. Lubos, E.; Loscalzo, J.; Handy, D.E. Glutathione Peroxidase-1 in Health and Disease: From Molecular Mechanisms to Therapeutic Opportunities. Antioxid. Redox Signal. 2011, 15, 1957-1997. [CrossRef]

22. Hu, Y.J.; Diamond, A.M. Role of glutathione peroxidase 1 in breast cancer: Loss of heterozygosity and allelic differences in the response to selenium. Cancer Res. 2003, 63, 3347-3351.

23. Jablonska, E.; Gromadzinska, J.; Peplonska, B.; Fendler, W.; Reszka, E.; Krol, M.B.; Wieczorek, E.; Bukowska, A.; Gresner, P.; Galicki, M.; et al. Lipid peroxidation and glutathione peroxidase activity relationship in breast cancer depends on functional polymorphism of GPX1. BMC Cancer 2015, 15, 1-12. [CrossRef] [PubMed]

24. Shen, Y.; Li, D.; Tian, P.; Shen, K.; Zhu, J.; Feng, M.; Wan, C.; Yang, T.; Chen, L.; Wen, F. The catalase C-262T gene polymorphism and cancer risk: A systematic review and meta-analysis. Medicine 2015, 94, e679. [CrossRef] [PubMed]

25. Bastaki, M.; Huen, K.; Manzanillo, P.; Chande, N.; Chen, C.; Balmes, J.R.; Tager, I.B.; Holland, N. Genotype-activity relationship for Mn-superoxide dismutase, glutathione peroxidase 1 and catalase in humans. Pharm. Genom. 2006, 16, 279-286. [CrossRef]

26. Ahn, J.; Nowell, S.; McCann, S.E.; Yu, J.; Carter, L.; Lang, N.P.; Kadlubar, F.F.; Ratnasinghe, L.D.; Ambrosone, C.B. Associations between Catalase Phenotype and Genotype: Modification by Epidemiologic Factors. Cancer Epidemiol. Biomark. Prev. 2006, 15, 1217-1222. [CrossRef]

27. Zaichick, V.Y.; Sviridova, T.V.; Zaichick, S.V. Zinc in the human prostate gland: Normal, hyperplastic and cancerous. Int. Urol. Nephrol. 1997, 29, 565-574. [CrossRef] [PubMed]

28. Costello, L.C.; Franklin, R.B. A Review of the Current Status and Concept of the Emerging Implications of Zinc and Zinc Transporters in the Development of Pancreatic Cancer. Pancreat. Disord. Ther. 2013, 1 (Suppl. 4), 1-8. [CrossRef] [PubMed]

29. Costello, L.C.; Feng, P.; Milon, B.; Tan, M.; Franklin, R.B. Role of zinc in the pathogenesis and treatment of prostate cancer: Critical issues to resolve. Prostate Cancer Prostatic Dis. 2004, 7, 111-117. [CrossRef] [PubMed]

30. Costello, L.C.; Levy, B.A.; Desouki, M.M.; Zou, J.; Bagasra, O.; Johnson, L.A.; Hanna, N.; Franklin, R.B. Decreased zinc and downregulation of ZIP3 zinc uptake transporter in the development of pancreatic adenocarcinoma. Cancer Biol. Ther. 2011, 12, 297-303. [CrossRef]

31. Costello, L.C.; Franklin, R.B. Decreased zinc in the development and progression of malignancy: An important common relationship and potential for prevention and treatment of carcinomas. Expert Opin. Ther. Targets 2017, 21, 51-66. [CrossRef] [PubMed]

32. Hoang, B.X.; Han, B.; Shaw, D.G.; Nimni, M.E. Zinc as a possible preventive and therapeutic agent in pancreatic, prostate, and breast cancer. Eur. J. Cancer Prev. 2016, 25, 457-461. [CrossRef]

33. Bae, S.N.; Lee, Y.S.; Kim, M.Y.; Kim, J.D.; Park, L.O. Antiproliferative and apoptotic effects of zinc-citrate compound (CIZAR(R)) on human epithelial ovarian cancer cell line, OVCAR-3. Gynecol. Oncol. 2006, 103, 127-136. [CrossRef]

34. Kim, E.S.; Lim, C.S.; Chun, H.J.; Keum, B.; Seo, Y.S.; Kim, Y.S.; Jeen, Y.T.; Lee, H.S.; Um, S.H.; Kim, C.D.; et al. Detection of Cu(I) and $\mathrm{Zn}(\mathrm{II})$ ions in colon tissues by multi-photon microscopy: Novel marker of antioxidant status of colon neoplasm. J. Clin. Pathol. 2012, 65, 882-887. [CrossRef]

35. Zhou, W.; Park, S.; Liu, G.; Miller, D.P.; Wang, L.I.; Pothier, L.; Wain, J.C.; Lynch, T.J.; Giovannucci, E.; Christiani, D.C. Dietary Iron, Zinc, and Calcium and the Risk of Lung Cancer. Epidemiology 2005, 16, 772-779. [CrossRef] [PubMed]

36. Kaczmarek, K.; Jakubowska, A.; Sukiennicki, G.; Muszyńska, M.; Jaworska-Bieniek, K.; Durda, K.; Huzarski, T.; SerranoFernandez, P.; Byrski, T.; Gronwald, J.; et al. Zinc and breast cancer risk. Hered. Cancer Clin. Pract. 2012, 10, A6. [CrossRef] 
37. Abdulla, M.; Biorklund, A.; Mathur, A.; Wallenius, K. Zinc and copper levels in whole blood and plasma from patients with squamous cell carcinomas of head and neck. J. Surg. Oncol. 1979, 12, 107-113. [CrossRef]

38. Woźniak, A.; Kujawa, A.; Seńczuk-Przybyłowska, M.; Kulza, M.; Gawecki, W.; Szybiak, B.; Herman, M.; Czarnywojtek, A.; Kurhańska-Flisykowska, A.; Chesy, P.; et al. Physiological metals in the serum, hair and nails of patients with head and neck cancer. Prz. Lek. 2012, 69, 785-797.

39. Varghese, I.; Sugathan, C.; Balasubramoniyan, G.; Vijayakumar, T. Serum Copper and Zinc Levels in Premalignant and Malignant Lesions of the Oral Cavity. Oncology 1987, 44, 224-227. [CrossRef] [PubMed]

40. Golasik, M.; Przybyłowicz, A.; Woźniak, A.; Herman, M.; Gawęcki, W.; Golusiński, W.; Walas, S.; Krejpcio, Z.; Szyfter, K.; Florek, E.; et al. Essential metals profile of the hair and nails of patients with laryngeal cancer. J. Trace Elem. Med. Biol. 2015, 31, 67-73. [CrossRef] [PubMed]

41. Pasha, Q.; Malik, S.; Shah, M.H. Statistical analysis of trace metals in the plasma of cancer patients versus controls. J. Hazard. Mater. 2008, 153, 1215-1221. [CrossRef] [PubMed]

42. Leone, N.; Courbon, D.; Ducimetiere, P.; Zureik, M. Zinc, Copper, and Magnesium and Risks for All-Cause, Cancer, and Cardiovascular Mortality. Epidemiology 2006, 17, 308-314. [CrossRef] [PubMed]

43. Wu, T.; Sempos, C.T.; Freudenheim, J.L.; Muti, P.; Smit, E. Serum iron, copper and zinc concentrations and risk of cancer mortality in US adults. Ann. Epidemiol. 2004, 14, 195-201. [CrossRef]

44. Fang, A.; Chen, P.; Wang, X.; Liu, Z.; Zhang, D.; Luo, Y.; Liao, G.; Long, J.; Zhong, R.; Zhou, Z.; et al. Serum copper and zinc levels at diagnosis and hepatocellular carcinoma survival in the Guangdong Liver Cancer Cohort. Int. J. Cancer 2019, 144, $2823-2832$. [CrossRef] [PubMed]

45. Michalska-Mosiej, M.; Socha, K.; Soroczyńska, J.; Karpińska, E.; Łazarczyk, B.; Borawska, M.H. Selenium, Zinc, Copper, and Total Antioxidant Status in the Serum of Patients with Chronic Tonsillitis. Biol. Trace Elem. Res. 2016, 173, 30-34. [CrossRef]

46. Wessells, K.R.; Brown, K.H. Estimating the Global Prevalence of Zinc Deficiency: Results Based on Zinc Availability in National Food Supplies and the Prevalence of Stunting. PLoS ONE 2012, 7, e50568. [CrossRef]

47. Franklin, R.B.; Costello, L.C. Zinc as an anti-tumor agent in prostate cancer and in other cancers. Arch. Biochem. Biophys. 2007, 463, 211-217. [CrossRef]

48. Yan, M.; Hardin, K.; Ho, E. Differential response to zinc-induced apoptosis in benign prostate hyperplasia and prostate cancer cells. J. Nutr. Biochem. 2010, 21, 687-694. [CrossRef] [PubMed]

49. Costello, L.C.; Franklin, R.B. Cytotoxic/tumor suppressor role of zinc for the treatment of cancer: An enigma and an opportunity. Expert Rev. Anticancer Ther. 2012, 12, 121-128. [CrossRef] [PubMed]

50. Ho, E. Zinc deficiency, DNA damage and cancer risk. J. Nutr. Biochem. 2004, 15, 572-578. [CrossRef]

51. Song, Y.; Leonard, S.W.; Traber, M.G.; Ho, E. Zinc deficiency affects DNA damage, oxidative stress, antioxidant defenses, and DNA repair in rats. J. Nutr. 2009, 139, 1626-1631. [CrossRef] [PubMed]

52. Jayaraman, A.K.; Jayaraman, S. Increased level of exogenous zinc induces cytotoxicity and up-regulates the expression of the ZnT-1 zinc transporter gene in pancreatic cancer cells. J. Nutr. Biochem. 2011, 22, 79-88. [CrossRef]

53. Kocdor, H.; Ates, H.; Aydin, S.; Cehreli, R.; Soyarat, F.; Kemanli, P.; Harmanci, D.; Cengiz, H.; Kocdor, M.A. Zinc supplementation induces apoptosis and enhances antitumor efficacy of docetaxel in non-small-cell lung cancer. Drug Des. Dev. Ther. 2015, 9, 3899-3909. [CrossRef] [PubMed]

54. Bastow, M.; Kriedt, C.L.; Baldassare, J.; Shah, M.; Klein, C. Zinc is a potential therapeutic for chemoresistant ovarian cancer. J. Exp. Ther. Oncol. 2011, 9, 175-181. [PubMed]

55. Kristal, A.R.; Stanford, J.L.; Cohen, J.H.; Wicklund, K.; Patterson, R.E. Vitamin and mineral supplement use is associated with reduced risk of prostate cancer. Cancer Epidemiol. Biomark. Prev. 1999, 8, 887-892.

56. González, A.; Peters, U.; Lampe, J.W.; White, E. Zinc Intake from Supplements and Diet and Prostate Cancer. Nutr. Cancer 2009, 61, 206-215. [CrossRef]

57. Epstein, M.M.; Kasperzyk, J.L.; Andrén, O.; Giovannucci, E.L.; Wolk, A.; Håkansson, N.; Andersson, S.-O.; Johansson, J.-E.; Fall, K.; Mucci, L.A. Dietary zinc and prostate cancer survival in a Swedish cohort. Am. J. Clin. Nutr. 2011, 93, 586-593. [CrossRef] [PubMed]

58. Sutton, A.; Khoury, H.; Prip-Buus, C.; Cepanec, C.; Pessayre, D.; Degoul, F. The Ala16Val genetic dimorphism modulates the import of human manganese superoxide dismutase into rat liver mitochondria. Pharmacogenetics 2003, 13, 145-157. [CrossRef]

59. Millikan, R.C.; Player, J.; de Cotret, A.R.; Moorman, P.; Pittman, G.; Vannappagari, V.; Chiu-Kit, J.T.; Keku, T. Manganese superoxide dis-mutase Ala-9Val polymorphism and risk of breast cancer in a population-based case-control study of African Americans and whites. Breast Cancer Res. 2004, 6, R264-R274. [CrossRef] [PubMed]

60. Cai, Q.; Shu, X.O.; Wen, W.; Cheng, J.R.; Dai, Q.; Gao, Y.T.; Zheng, W. Genetic polymorphism in the manganese superoxide dismutase gene, antioxidant intake, and breast cancer risk: Results from the Shanghai Breast Cancer Study. Breast Cancer Res. 2004, 6, R647-R655. [CrossRef] [PubMed]

61. Mao, C.; Qiu, L.-X.; Zhan, P.; Xue, K.; Ding, H.; Du, F.-B.; Li, J.; Chen, Q. MnSOD Val16Ala polymorphism and prostate cancer susceptibility: A meta-analysis involving 8962 Subjects. J. Cancer Res. Clin. Oncol. 2010, 136, 975-979. [CrossRef] [PubMed]

62. Yi, J.F.; Li, Y.M.; Liu, T.; He, W.T.; Li, X.; Zhou, W.C.; Kang, S.L.; Zeng, X.T.; Zhang, J.Q. Mn-SOD and CuZn-SOD polymorphisms and interactions with risk factors in gastric cancer. World J. Gastroenterol. 2010, 16, 4738-4746. [CrossRef] [PubMed] 
63. Zienolddiny, S.; Campa, D.; Lind, H.; Ryberg, D.; Skaug, V.; Stangeland, L.B.; Canzian, F.; Haugen, A. A comprehensive analysis of phase I and phase II metabolism gene polymorphisms and risk of non-small cell lung cancer in smokers. Carcinogenesis 2008, 29, 1164-1169. [CrossRef] [PubMed]

64. Rajaraman, P.; Hutchinson, A.; Rothman, N.; Black, P.M.; Fine, H.A.; Loeffler, J.S.; Selker, R.G.; Shapiro, W.R.; Linet, M.S.; Inskip, P.D. Oxidative response gene polymorphisms and risk of adult brain tumors. Neuro-Oncol. 2008, 10, 709-715. [CrossRef]

65. Ezzikouri, S.; El Feydi, A.E.; Chafik, A.; Afifi, R.; El Kihal, L.; Benazzouz, M.; Hassar, M.; Pineau, P.; Benjelloun, S. Genetic polymorphism in the manganese superoxide dismutase gene is associated with an increased risk for hepatocellular carcinoma in HCV-infected Moroccan patients. Mutat. Res. Toxicol. Environ. Mutagen. 2008, 649, 1-6. [CrossRef] [PubMed]

66. Olson, S.H.; Carlson, M.D.; Ostrer, H.; Harlap, S.; Stone, A.; Winters, M.; Ambrosone, C.B. Genetic variants in SOD2, MPO, and NQO1, and risk of ovarian cancer. Gynecol. Oncol. 2004, 93, 615-620. [CrossRef] [PubMed]

67. Yoshida, T.; Kageyama, S.; Isono, T.; Yuasa, T.; Kushima, R.; Kawauchi, A.; Chano, T. Superoxide dismutase 2 expression can predict prognosis of renal cell carcinoma patients. Cancer Biomark. 2018, 22, 755-761. [CrossRef]

68. Chang, B.; Yang, H.; Jiao, Y.; Wang, K.; Liu, Z.; Wu, P.; Li, S.; Wang, A. SOD2 deregulation enhances migration, invasion and has poor prognosis in salivary adenoid cystic carcinoma. Sci. Rep. 2016, 6, 25918. [CrossRef]

69. Janssen, A.M.; Bosman, C.B.; van Duijn, W.; de Ruit, M.M.O.-V.; Kubben, F.J.; Griffioen, G.; Lamers, C.B.; van Krieken, J.H.; van de Velde, C.J.; Verspaget, H.W. Superoxide dismutases in gastric and esophageal cancer and the prognostic impact in gastric cancer. Clin. Cancer Res. 2000, 6, 3183-3192. [PubMed]

70. Ashtekar, A.; Huk, D.; Magner, A.; la Perle, K.M.D.; Boucai, L.; Kirschner, L.S. Alterations in Sod2-Induced Oxidative Stress Affect Endocrine Cancer Progression. J. Clin. Endocrinol. Metab. 2018, 103, 4135-4145. [CrossRef]

71. Ambrosone, C.B.; Ahn, J.; Singh, K.K.; Rezaishiraz, H.; Furberg, H.; Sweeney, C.; Coles, B.; Trovato, A. Polymorphisms in genes related to oxidative stress (MPO, MnSOD, CAT) and survival after treatment for breast cancer. Cancer Res. 2005, 65, 1105-1111. [PubMed]

72. Geng, R.; Chen, Z.; Zhao, X.; Qiu, L.; Liu, X.; Liu, R.; Guo, W.; He, G.; Li, J.; Zhu, X. Oxidative Stress-Related Genetic Polymorphisms Are Associated with the Prognosis of Metastatic Gastric Cancer Patients Treated with Epirubicin, Oxaliplatin and 5-Fluorouracil Combination Chemotherapy. PLoS ONE 2014, 9, e116027. [CrossRef] [PubMed]

73. Choi, J.Y.; Neuhouser, M.L.; Barnett, M.; Hudson, M.; Kristal, A.R.; Thornquist, M.; King, I.B.; Goodman, G.E.; Ambrosone, C.B. Poly-morphisms in oxidative stress-related genes are not associated with prostate cancer risk in heavy smokers. Cancer Epidemiol. Biomark. Prev. 2007, 16, 1115-1120. [CrossRef] [PubMed]

74. Udler, M.; Maia, A.-T.; Cebrian, A.; Brown, C.; Greenberg, D.; Shah, M.; Caldas, C.; Dunning, A.M.; Easton, D.; Ponder, B.; et al Common Germline Genetic Variation in Antioxidant Defense Genes and Survival After Diagnosis of Breast Cancer. J. Clin. Oncol. 2007, 25, 3015-3023. [CrossRef]

75. He, C.; Qureshi, A.A.; Han, J. Polymorphisms in genes involved in oxidative stress and their interactions with lifestyle factors on skin cancer risk. J. Dermatol. Sci. 2010, 60, 54-56. [CrossRef]

76. Bhatti, P.; Stewart, P.A.; Hutchinson, A.; Rothman, N.; Linet, M.S.; Inskip, P.D.; Rajaraman, P. Lead Exposure, Polymorphisms in Genes Related to Oxidative Stress, and Risk of Adult Brain Tumors. Cancer Epidemiol. Biomark. Prev. 2009, 18, 1841-1848. [CrossRef] [PubMed]

77. Sutherland, A.; Kim, D.-H.; Relton, C.; Ahn, Y.-O.; Hesketh, J. Polymorphisms in the selenoprotein S and 15-kDa selenoprotein genes are associated with altered susceptibility to colorectal cancer. Genes Nutr. 2010, 5, 215-223. [CrossRef]

78. Ratnasinghe, D.; Tangrea, J.A.; Andersen, M.R.; Barrett, M.J.; Virtamo, J.; Taylor, P.R.; Albanes, D. Glutathione peroxidase codon 198 polymorphism variant increases lung cancer risk. Cancer Res. 2000, 60, 6381-6383. [PubMed]

79. Ravn-Haren, G.; Olsen, A.; Tjonneland, A.; Dragsted, L.O.; Nexø, B.A.; Wallin, H.; Overvad, K.; Raaschou-Nielsen, O.; Vogel, U. Associations between GPX1 Pro198Leu polymorphism, erythrocyte GPX activity, alcohol consumption and breast cancer risk in a prospective cohort study. Carcinogenesis 2006, 27, 820-825. [CrossRef]

80. Raaschou-Nielsen, O.; Sørensen, M.; Hansen, R.D.; Frederiksen, K.; Tjønneland, A.; Overvad, K.; Vogel, U. GPX1 Pro198Leu polymorphism, interactions with smoking and alcohol consumption, and risk for lung cancer. Cancer Lett. 2007, 247, 293-300 [CrossRef]

81. Tang, H.; Dong, X.; Day, R.S.; Hassan, M.M.; Li, D. Antioxidant genes, diabetes and dietary antioxidants in association with risk of pancreatic cancer. Carcinogenesis 2010, 31, 607-613. [CrossRef] [PubMed]

82. Wang, J.; Sun, T.; Yang, M.; Lin, D.-X.; Tan, W.; Li, K.-J.; Xiao, Y. Association of genetic polymorphisms in selenoprotein GPX1 and TXNRD2 with genetic susceptibility of gastric cancer. Zhonghua Yu Fang Yi Xue Za Zhi 2008, 42, 511-514.

83. Ezzikouri, S.; El Feydi, A.E.; Afifi, R.; Benazzouz, M.; Hassar, M.; Pineau, P.; Benjelloun, S. Polymorphisms in antioxidant defence genes and susceptibility to hepatocellular carcinoma in a Moroccan population. Free Radic. Res. 2010, 44, 208-216. [CrossRef] [PubMed]

84. Erdem, O.; Eken, A.; Akay, C.; Arsova-Sarafinovska, Z.; Matevska, N.; Suturkova, L.; Erten, K.; Özgök, Y.; Dimovski, A.; Sayal, A.; et al. Association ofGPX1polymorphism, GPX activity and prostate cancer risk. Hum. Exp. Toxicol. 2012, 31, 24-31. [CrossRef]

85. Goerlitz, D.; El Daly, M.; Abdel-Hamid, M.; Doa'a, A.S.; Goldman, L.; El Kafrawy, S.; Hifnawy, T.; Ezzat, S.; Abdel-Aziz, M.A.; Zaghloul, M.S.; et al. GSTM1, GSTT1 null variants, and GPX1 single nucleotide polymorphism are not associated with bladder cancer risk in Egypt. Cancer Epidemiol. Biomark. Prev. 2011, 20, 1552-1554. [CrossRef] [PubMed] 
86. Liu, K.; Jin, M.; Xiao, L.; Liu, H.; Wei, S. Distinct prognostic values of mRNA expression of glutathione peroxidases in non-small cell lung cancer. Cancer Manag. Res. 2018, 10, 2997-3005. [CrossRef]

87. Lee, J.R.; Roh, J.L.; Lee, S.M.; Park, Y.; Cho, K.J.; Choi, S.H.; Nam, S.Y.; Kim, S.Y. Overexpression of glutathione peroxidase 1 predicts poor prognosis in oral squamous cell carcinoma. J. Cancer Res. Clin. Oncol. 2017, 143, 2257-2265. [CrossRef] [PubMed]

88. Zhang, Q.; Xu, H.; You, Y.; Zhang, J.; Qicheng, Z. High Gpx1 expression predicts poor survival in laryngeal squamous cell carcinoma. Auris Nasus Larynx 2018, 45, 13-19. [CrossRef]

89. Dequanter, D.; Dok, R.; Koolen, L.; Vander, L.; Poorten, V.V.; Nuyts, S. Prognostic Significance of Glutathione Peroxidase Levels (GPx1) in Head and Neck Cancers. Front. Oncol. 2017, 7. [CrossRef]

90. Zhang, H.; Zhao, W.; Gu, D.; Du, M.; Gong, W.; Tan, Y.; Wang, M.; Wen, J.; Zhai, Y.; Xu, Z. Association of Antioxidative Enzymes Polymorphisms with Efficacy of Platin and Fluorouracil-Based Adjuvant Therapy in Gastric Cancer. Cell Physiol. Biochem. 2018, 48, 2247-2257. [CrossRef] [PubMed]

91. Forsberg, L.; de Faire, U.; Marklund, S.L.; Andersson, P.M.; Stegmayr, B.; Morgenstern, R. Phenotype Determination of a Common Pro-Leu Polymorphism in Human Glutathione Peroxidase 1. Blood Cells Mol. Dis. 2000, 26, 423-426. [CrossRef] [PubMed] 